\title{
Difficulties Facing Students in English Language Conversation
}

\author{
Alqahtani Mofareh A. ${ }^{1}$ \\ ${ }^{1}$ English Department, Civilian Studies, King Khaled Military Academy, Riyadh, Saudi Arabia \\ Correspondence: Alqahtani Mofareh A., English Department, Civilian Studies, King Khaled Military Academy, \\ Riyadh, Saudi Arabia.
}

Received: September 1, 2019

Accepted: September 11, 2019

Online Published: September 17, 2019

doi:10.5430/irhe.v4n3p51

URL: https://doi.org/10.5430/irhe.v4n3p51

\begin{abstract}
This study addresses the poor language proficiency of English language students, particularly in terms of their conversational skills and/or ability to achieve the desired standards of fluency in either the classroom environment or public sphere. The many factors which directly affect students' performance in speaking fluent English include the fear of making errors. The present study therefore aims to identify the perceived difficulties which language students associate with the study and utterance of English. To this end, the conducted research was descriptive in nature and sought to determine the various elements which are perceived as especially challenging for students and to devise effective solutions through appropriate teaching styles, methodologies and strategies which are driven and supported by the relevant contemporary technology. In addition to fear, certain factors relate to individuated student character and practices, and many students report feelings of shyness and potential embarrassment. Distrust also constitutes a significant obstacle, along with issues surrounding teaching methods, teacher inefficiency, and/or the lack of up-to-date pedagogies. To fully investigate this issue, a quantitative survey instrument containing multiple questions was undertaken in addition to a number of interviews with a random sample of students and teachers in order to elicit the main student challenge in speaking English. The results demonstrated that the majority of the students were unable to speak English either correctly or confidently. The percentages which varied between average, weak, and very weak, were attributed to a general weakness in English grammar, vocabulary, syntax, poor fluency in speech, low understanding of overall grammar frameworks, and inaccurate pronunciation. In light of this, the present study sought to provide useful suggestions to resolve student conversational problems. To this end, the researcher elucidated the research problem, importance, objectives, hypotheses and methodologies, as well as drawing conclusions. Finally, the researcher outlined a number of recommendations directly relevant to resolving the complex issue.
\end{abstract}

Keywords: speaking, difficulties, skills

\section{Introduction}

As the contemporary world's foremost language, English is now the principal medium of international communication and, as such, is intrinsic to information and knowledge in business, technology, education across multiple disciplines, health, and science. It therefore follows that English represents the global link between students and all forms of knowledge. With this in mind, the core English language skill which students now need more than ever, is the ability to converse fluently. Conversation skills rest on student comprehension of the language requirements of grammar and vocabulary which enable the correct formulation of speech and on whether students can ultimately master the ability to speak correctly. Noonan (1991) asserted that competent speaking skills are deemed the single most important aspect of ESL/EFL studies by most learners. It therefore follows that linguistic success is measured in terms of the ability to carry out a conversation in the target language.

It is increasingly clear that in order to meet the personal and professional demands of $21^{\text {st }}$ century life students need to practice direct communication with their teacher both through routine school and extramural activities. Nonetheless, numerous studies concur that around $75 \%$ of students still experience difficulties in honing their conversation skills. Indeed, while many students become proficient in the abstract frameworks of grammar, ongoing difficulties in transposing them to actual conversation has become the biggest challenge for English language students. Within the process of communication students are often required to build on ideas, express perceptions, and articulate reasoning; efforts which can be considerably compromised by poor conversational skill. As such, teachers should concentrate on delivering communication techniques along with other language skills such as vocabulary and 
grammar, by applying modern technological aids to achieve fluency in oral communication in accordance with the main objectives of the majority of students. While many ESL/EFL students feel frustrated by their inability to participate in 'real' conversations, they maintain that such oral communication difficulties can be tackled through expanded vocabulary. This assumption is incorrect. On the contrary, it is evident that to confront difficulties, minimise confusion, and properly assimilate langauge, students should be guided by teaching methodologies which elucidate word meanings and engage with strategies specifically designed to combat issues of student self-confidence, shyness, and anxiety.

\section{Previous Studies}

\section{- Difficulties Faced by College Student in Speaking English: A Sociological Reflection}

\section{S. Rasheedha Banu \& Rajathurai Nishanthi (2017)}

Just as English as a second language is both inseparable and unavoidable in the Indian education system, it also inheres sufficient physical, intellectual and emotional involvement to successfully transmit and interpret linguistic messages. This article isolated the various causes of student difficulty in communicating in English and suggested a number of possible solutions to offset such problems. The descriptive nature of this paper highlights the difficulties faced by college students in speaking English within a sociological context.

- Problems and Difficulties of Speaking That Encounter English Language Students at Al Quds Open University

Ahmed Maher Mahmoud Al Nakhalah (2016)

The researcher proposes that although students are necessarily delimited in the time allocated to learning English within class, they are not sufficiently encouraged to familiarise themselves with the language by practicing outside of class. This lack of additional practice and familiarity is ultimately manifested in senior high-school student difficulties with English communication.

\section{- An Investigation of the Difficulties Faced by EFL Undergraduates in Speaking Skills}

Dina A. Al-Jamal \& Ghadeer A. Al-Jamal 2014

The researcher conducted a study which aimed to describe difficulties that may be encountered at an EFL setting. The sample was stratified random as drawn from six Jordanian public universities. Initial survey questionnaires were augmented by semi-structured interviews conducted with 64 of the 566 students who responded to the survey. The findings of the study exposed a perceived failure of EFL students' speaking skills in English to explain such difficulty. The results of the study further showed a 'low' speaking proficiency level among EFL undergraduates along with negligible instruction of the speaking skill at university courses' level. More difficulties highlighted by this study were issues of communication in L1, large classes, and lack of time.

\section{- Problem-Based Conversations}

Matthew Miller (2008)

These searching conversations regarding teaching subject matter, connected course requirements to field experiences, classroom management, and pedagogy, and proved helpful in promoting empathy with peer predicaments, and in offers of professional advice and support. Such peer-to-peer conversations diverged from those with supervisors and professors, as they revolved around similar problems and shared predicaments.

\section{- $\quad$ The Role of Conversation in Teacher Learning Contexts}

Lev Vygotsky (1978)

This research supports the theory that knowledge and learning are social enterprises which occupy such particular physical and social positions as to attach a high value to the role of language and social interaction in learning. Vygotsky highlighted the importance of talk in social situations as prerequisite to understanding new concepts.

\section{Research Problem}

The basic research problem of this study rests on determining the precise difficulties and challenges faced by students in learning English language conversation skills. The study also examines the range of techniques and procedures required to elevate student conversation skills to a satisfactory standards, and analyses student efficiency in assimilating English conversation skills in comparison with previous findings of low student ability to communicate in the formal classroom context or even casually amongst themselves. To this end, the study also evaluates the efficacy of various teaching tools, methodologies, and strategies, and the availability and/or utility of 
modern technology in delivering English communication and conversation skills. Research demonstrates that while students vary in their understanding of ancillary language skills such as writing, reading and vocabulary, communication skills remain the consistently weak link which gives rise to student frustration with 'real-life' usage. Research should therefore identify the various causes of such difficulties and devise logical and practicable solutions. The present study also acts to remind officials and other interested parties of the critical importance of redressing these essential teaching and learning problems.

\subsection{Research Questions}

The key questions of the present study are as follows:

1. What difficulties are faced by students learning conversation skills?

2. To what extent do students find it difficult to communicate in English?

3. What is the effect of these problems on the student's language capabilities?

4. Are certain teachers and/or methods of teaching responsible for student problems?

5. What are the best ways and means to resolve these problems?

\section{Significance of Research}

The research aims underpinning the present study may be summarized as follows:

1. To determine whether local English language teachers are sufficiently qualified to deliver student English conversation skills with linguistic and grammatical precision.

2. To identify the nature and extent of the difficulties faced by students in conversation and devise appropriate teaching solutions.

3. To assess the quality of tools, methods, and other teaching aids used by English teachers, and to identify their utility in teaching student conversation skills.

4. To encourage teachers to adopt innovative ideas and methods in order to deliver more timely and effective English language conversation skills.

5. To promote programs which assist students to hone their English communication both in and out of the classroom in order to boost their general conversational abilities.

6. To convene regular seminars which encourage students to communicate in English.

7. To break down the barriers of student fear and shame when practicing English conversation with a specialist teacher.

\section{Objectives}

This study aims to identify the following traits and characteristics:

1. inability of students to learn English language conversation skills accurately

2. factors behind the difficulties faced by students seeking to communicate in English

3. teaching methods adopted to deliver English conversation skills

4. practical solutions which enable students to master English communication skills

5. advocate for officials and English teachers to confront the seriousness of this problem and to expedite the finding of definitive solutions

\section{Methodology}

The researcher used the descriptive research methodology to collect data on the extent to which students learn conversation skills in English and the teaching styles that follow as a fundamental method. This research focuses on identifying the difficulties faced by students during their training to acquire English fluent language skills. It is noted that the method of descriptive research focuses on the knowledge and determination of student behaviour and performance in relation to the prescribed curriculum. These also include descriptions and extrapolations of student status to determine overall standards and student ability to assimilate conversation skills. According to the data it is evident that student cases diverged on the basis of individual attitude, perception, and ability to practice language in a positive way. The application of descriptive research is grounded on the assumption that difficulties and challenges are identified with respect to the language communication and psychological problems facing the student. The relevant data was elicited through a survey which was disseminated to a random sample of students in order to 
determine student capacity to assimilate and use English conversation skills.

\subsection{Technical Terms}

DIFFICULTY: The quality or state of being hard to undertake, deal with, or understand.

ENGLISH: The language spoken in the UK, the US, and in many other countries; particularly the American/British form.

STUDENT: A person who is formally engaged in learning at a college or university.

CONVERSATION: A discussion between two or more participants in which thoughts, feelings, and ideas are expressed, questions are asked and answered, and/or news and information is exchanged.

\section{Results}

The data from this study confirms that a high proportion of ESL/EFL students are unable to strike up a conversation in English.

This failing is attributed to a number of factors, including poor teaching, the use of traditional teaching methods that do not meet contemporary linguistic needs, the adoption of teaching methods that lack adequate direction, and the unavailability or use of modern technology. In addition, the study determined a number of student-centred causes such as fears based on excessive shyness or potential embarrassment which is merely compounded by a general reluctance to converse in English. The conversational difficulties reported by students are summarized as follows:

1. inadequate English grammar

2. insufficient vocabulary

3. lack of linguistic skills

4. inaccurate pronunciation

5. shyness and anxiety

6. low self-confidence

However, a number of more positive studies have demonstrated how such difficulties can be overcome with the gradual introduction of appropriate teaching means and modern methods, and confirmed that improved teacher-training and student motivation can translate into enhanced learning outcomes.

\section{Discussion}

This study sought to identify the difficulties and challenges faced by students in learning English language conversation skills. The statistics revealed a general weakness in the level of communication among students. This was attributed to several factors, including the individual teacher and the teaching methods used, and additional considerations obtaining to the student. Overall, the study reaffirmed that a lack of adequate teacher training and adherence to obsolete teaching methods are among the core factors perpetuating to the consistently poor levels of student fluency. These issues are only exacerbated by student problems in coping with the demands of English grammar, including the correct use of the present simple, past, the future tense, initial pronunciation errors which can grow into major problems, and the vagaries of English vocabulary meanings and synonyms. The study also highlighted a marked student anxiety around losing face by speaking incorrect English in front of their classmates, with many admitting they prefer to remain silent than to risk such embarrassment

The stated aim of the study was to generate solutions to overcome English language conversation difficulties. To this end, students must be made aware that confidence is key. Indeed, the need and desire to communicate with others which forms the 'language bridge' should be stressed as integral to the mastering of fluency and accuracy in the target language. For their part, teachers must be more open to pedagogical innovations which meet the requirements and expectations of the contemporary student and harness the affordances of available technology to communicate with students, as well as holding regular seminars for students to break down fear barriers and hone conversation skills by talking together in their free time.

The researcher conducted interviews with a random sample of English language learners and teachers in tandem with a quantitative survey. As anticipated, the ensuing results revealed that a significant percentage of students were unable to strike up a conversation in English. This was attributed poor quality teaching, the use of obsolete teaching methods that do not meet contemporary needs, the adoption of teaching methods that lack proper formulation and/or direction, and the unavailability or use of modern technology. 


\section{Findings}

1. The difficulties faced by students learning English conversation skills was manifested in fear and student reluctance to speak English, in addition to inadequate vocabulary, poor linguistic formulation, and low overall knowledge of grammatical structure.

2. It is evident that student inability to communicate in the English language fosters frustration and exacerbates anxieties about entering into any conversation initiated by others.

3. As a direct result of this frustration, students report opting out of participation in any English classroom discussion or regular seminars. In maintaining such silence students ultimately lose vital opportunities to practice and master their English communication skills.

4. It is clear that the language teacher bears much responsibility for inadequate training and an adherence to obsolete pedagogies which perpetuate low learner outcomes.

5. The results underscore how imperative it is to train language teachers in relevant contemporary methods and to urge them to adopt advanced technological teaching aids. Moreover, it reaffirms that teachers should encourage and motivate all langauge learners to take part in either formal seminars or extramural dialogues as a means of minimising conversational fears and hesitations and to foreground the English langauge as an organic and entirely learnable means of communication.

\section{Limitations of the Study}

Since the overall study sample targeted Bachelor Degree students of Riyadh University who were based on the main university campus for the 2018/19 Academic Year, certain research limitations obtaining to generalisability and replication came to light during the course of the study. These are acknowledged and outlined below as follows:

1. Spatial/geographic limitations: the study exclusively focused on the difficulties experienced by English language students enrolled in schools and universities in Riyadh, Saudi Arabia.

2. Time limitations: the research period necessarily aligned with the 2018/19 Academic year (9 months).

3. Field limitations: the sample set of surveyed students was randomised rather than purposive.

4. Human/numerical limitations: the number of surveyed school and university students ranged from 100 to 150.

5. Undergraduate students were assumed to be most in greater need of the potential assistance afforded by this study than other learner categories and beneficiaries.

\section{Recommendations}

The following recommendations aim to offset ESL/EFL student conversational challenges through:

1. Adoption of teaching methods which harness modern technology, such as audio and visual effects, and projection screens, which enable students to assimilate conversational skills with greater ease and enjoyment.

2. Teacher encouragement for students to strike up peer classroom conversations.

3. Mitigating student fear, shyness, and general reluctance to speak English.

4. Reframing the process of conversation by presenting langauge as an organic tool of communication.

5. Convening regular seminars for students to practice speaking to each other in English.

6. Encouraging students to participate in external fora and ESL/EFL associations and to speak with others to improve overall fluency

\section{Conclusion}

The results of the study demonstrate that the difficulties and challenges faced by students when speaking in English comprise a number of factors which need direct and practical solutions. These include the lack of adequate English language teacher-training and the unavailability or use of means which enable students to communicate among themselves. The study showed that foremost among the many conversation problems faced by students were low self-confidence around speaking in class, a largely unfounded fear of embarrassment caused by potential mistakes, imprecise understanding of English vocabulary and grammar, and incorrect word and/or sentence articulation.

Since the researcher further observed a number of attendant linguistic and psychological problems, the 
recommendations offered to mitigate such difficulties and instead permit students to assimilate language, addressed the same challenges and experiences of others in the use of means and methodologies. In light of this, the researcher urges education officials and all relevant stake-holders to redouble their current efforts to devise and implement appropriate strategies to boost the level of overall student capability in this vital context.

\section{References}

Aftat, M. (2008). Motivation and Genuine learning. Retrieved March 15, 2011, from http://www.englishteacher1.com/motivation.html

Ahmed Maher Mahmoud Al Nakhalah. (2016, December). Problems and Difficulties of Speaking That Encounter English Language Students at Al Quds Open University. International Journal of Humanities and Social Science Invention, 5(12), 96-101.

Babu, R. (2010). Teaching Spoken English for Non-native Students: Problems, Solutions and Techniques. Retrieved March 15, 2011, from http://www.eltweekly.com/elt-newsletter/2010/06/60-article-teaching-spoken-English-for-non-native-students-p roblems-solutions-and-techniques-by-a-ramesh-babu/

Baldwin, C. (2011). How to Overcome Shyness During an Oral Presentation. Retrieved February 17, 2011, from http://www.ehow.com/how_7852354_overcome-shyness-during-oral-presentation.html

Bowen, T. (2005). Methodology: Shy Students: An Article Offering Suggestions and Advice on Teaching Shy Students. $\quad$ Retrieved March 15, for http://www.onestopenglish.com/support/ask-the-experts/methodologyquestions/methodology-shystudents/1463 85.article

Brown, H. D. (2001). Teaching by Principles: An Interactive Approach to Language Pedagogy. Englewood Cliffs: Prentice Hall.

Chien, C-N., Lee. W., \& Kao, L-H. (2008). Collaborative Teaching in an ESP Program. Asian EFL Journal, 10(4), 120-125.

Chinmoy, S. (2007). How to Overcome Shyness. Retrieved February 17, 2011, from http://www.srichinmoybio.co.uk/2007/07/how-to-overcome- shyness.html

Dina, A. Al-J., \& Ghadeer, A. Al-J. (2014). An Investigation of the Difficulties Faced by EFL Undergraduates in Speaking Skills. English Language Teaching, 7(1). https://doi.org/10.5539/elt.v7n1p19

Gebhard, G. J. (2000). Teaching English as a Foreign or Second Language. USA: The University of Michigan Press.

Han, E. (2010). Academic Discussion Tasks: A Study of EFL Students' Perspectives. Asian EFL Journal, 9(1), 9.

Harmer, J. (2007). How to Teach English. China: Pearson Education Limited. https://doi.org/10.1093/elt/ccn029

He, S. X., \& Chen, A. J. Y. (2010). How to Improve Spoken English. Retrieved February 19, 2010, from http://sites.google.com/site/languagejournal/Home/how-to-improvespoken-English

Hieu, T. (2011). Students Lack Confidence to Use English. Retrieved July15, 2011, from http://vietnamnews.vnagency.com.vn/Talk-Aroundtown/212262/Students-lack-confidence-to-use-English.html

Horwitz, E. K., \& Horwitz, M. B. (1986). Foreign Language Classroom Anxiety. Joann Cope Source: The Modern Language Journal, 70(2), Summer, 125-130. https://doi.org/10.1111/j.1540-4781.1986.tb05256.x

Juhana. (2012). Psychological Factors That Hinder Students from Speaking in English Class (A Case Study in a Senior High School in South Tangerang, Banten, Indonesia) The English Department. Indonesia Open University- Journal of Education and Practice, 3(12). Retrieved from www.iiste.org

Kayi, H. (2006). Teaching Speaking: Activities to Promote Speaking in a Second Language. Retrieved March 19, 2010, from http://iteslj.org/Techniques/Kayi-TeachingSpeaking.html

Keramida, A. (2009). Helping Students Overcome Foreign Language Speaking Anxiety in the English Classroom: Theoretical Issues and Practical Recommendations. International Education Studies, 2(4). https://doi.org/10.5539/ies.v2n4p39

Kim, S. (2006). Coping with Cultural Obstacles to Speaking English in the Korean Secondary school context. EFL Asian Journal, 4-11.

Kubo, M. (2009). Extensive Pair Taping For College Students in Japan: Action Research In Confidence and Fluency Building. Accents Asia. Retrieved March 15, 2011, from http://accentsasia.org/3-1/kubo.pdf 
Kurtus, R. (2001). Overcome the Fear of Speaking to Group. Retrieved June 20, 2010, from http://www.school-for-champions.com/speaking/fear.htm

Liu, M. (2007, May). Anxiety in Oral English Classrooms: A Case Study in China. Indonesian Journal of English Language Teaching, 3(1), 119-121.

Liu, M., \& Huang, W. (2010). An Exploration of Foreign Language Anxiety and English Learning Motivation. Education Research International, 2011.

Matthew, M. (2008). Problem-Based Conversations: Using Preservice Teachers' Problems as a Mechanism for Their Professional Development. Teacher Education Quarterly, 35(4), 77-98.

Middleton, F. (2009). Overcome Your Fear Of Speaking Foreign Languages. Retrieved March 17, 2010, from http://www.eslteachersboard.com/cgi-bin/language/index.pl?page=2;read=1071

Nascente, R. M. M. (2001). Practical Ways to Help Anxious Learners. Retrieved June 20, 2010, from http://www3.telus.net/linguisticsissues/anxious.html

Noon-ura, S. (2008). Teaching Listening Speaking Skills to Thai Students with Low English Proficiency.

Nunan, D. (1999). Second Language Teaching \& Learning. USA. Heinle \& Heinle Publisher.

Pesce, C. (2011). Speak Up! Sure-fire Ways to Help Teens and Adults Overcome Shyness. Retrieved March 15, 2011, from http://busyteacher.org/4276-speak-up-sure-fire-ways-to-help-teens-and-adults.html

Pinter, A. (2006). Teaching Young Learners. Oxford: Oxford University Press.

Rasheedha, B., \& Rajathurai, N. (2017, May-June). Difficulties Faced by College Student in Speaking English - A Sociological Reflection. International Journal of Trend in Research and Development, 4(3). Retrieved from www.ijtrd.com

Richard, J. C. (2008). Teaching Listening and Speaking: From Theory to Practice. Cambridge: Cambridge PressUniversity.

Robby, S. (2010). Conquer Your Fear of Making Mistakes when Speaking English. Retrieved March 15. 2011, from http://englishharmony.com/conquer-fear-of-making-mistakes-when-speaking-English/

Samira, Al H. (2014). Speaking Difficulties Encountered by Young EFL Learners. International Journal on Studies in English Language and Literature (IJSELL), 2(6), 22-30.

Sato, K. (2003). Improving Our Students Speaking Skills: Using Selective Error Correction and GroupWork to Reduce Anxiety and Encourage Real Communication. Japan: Akita Prefectural.

Saurik. (2011). Learning English The Easy way!. Retrieved March 15, 2011, from http://guides.wikinut.com/Learning-English-The-Easy-Way!/2wuchx26/

Schwartz, R. L. (2005). Taking a Closer Look at Struggling ESOL Learners. Retrieved March 3, 2011, from http://www.ncsall.net/?id=994

Thornbury, S. (2005). How to Teach Speaking. Essex: Pearson Education Limited.

Tiono, N. I., \& Sylvia, A. (2004). The Types of Communication Strategies Used by Speaking Class Students with Different Communication Apprehension Levels in English Department of Petra Christian University, Surabaya. A Thesis, Petra Christian University.

Vygotsky, L. S. (1978). Mind in Society. Cambridge, MA: Harvard University Press.

Yan, H. (2007, April). Investigating the Difficulties in Speaking English for Academic Purposes: A Case Study of an Overseas Chinese Student. China: Sino-US English Teaching, 4(4).

Yeon Lim, H. (2003, May). Successful Classroom Discussions with Adult Korean ESL/EFL Learners. The Internet TESL Journal, IX(5).

Yi Htwe, Y. (2007). Shyness Main Obstacle to Learning English. Retrieved March 15, 2011, from http://no371/n010.htm

Zhao, N. (2007). A Study of High School Students' English Learning Anxiety. The Asian EFL Journal Quarterly, 9(3).

Zhou, N., \& et al.. (2004). How English as a Second Language Affects Chinese Students Giving Presentations During Class in U.S.A. Thesis Proposal: Graduate School of Marietta College.

Zua, L. (2008). Exploring the Affective Factors Influencing Teaching of Spoken English. Retrieved February 19, 2011, from http://okarticle.com/html/Thesis/20080104/26.html 